\title{
DOMESTIC VIOLENCE ON WOMAN: A SOCIOLOGICAL ANALYSIS
} Dr. Vijayalaxmi Biradar *1

${ }^{* 1}$ Associate Professor, Department of Sociology, Government P.G. Centre, Gulbarga, INDIA

\begin{abstract}
:
Violence against women is one of the old paradoxes of Indian Society. Contradictory statements about glorifying and condemning women are found in abundant measure. In Indian society, we talk about equality, dignity and respect for women, and goes to the extent of saying that "Gods reside where women are worshipped" at the practical operational level the society. However, follows practices that are quite contrary to its preaching's. In one go the society considers women, as goddesses and in another go as slaves, but never as human beings with dignity and self-respect. The rhetoric apart, dual standards for men and women have paved the way for gradual deterioration of women's position. Systemic degradation, inferiority and sub ordination is thus, an old theme of ancient vintage (Social Welfare: 2008).
\end{abstract}

Keywords:

Violence, Empowerment, Social Welfare, Freedom of Women, Human Rights.

Cite This Article: Dr. Vijayalaxmi Biradar, "Domestic Violence on Woman: A Sociological Analysis.” International Journal of Research - Granthaalayah, Vol. 3, No. 2(2015): 90-100.

\section{INTRODUCTION}

Nameless Crimes, Blameless victims- Behind closed doors and drawn curtains, there is an anguished cry, quickly smothered and silenced. It is the cry of pain, of humiliation, of shame that is extinguished as quickly as it arises. This tragedy unfolds silently and insidiously within the four walls of the home. The one place where women should be most secure and safe is the place of their torture and degradation. Violence against women is a universal phenomenon that cuts across class, creed and country. It is inversely proportional to the status of women in society. In communities that value women, violence has no lace. In patriarchal societies where women are objectified and equated to property or money, violence is omnipresent.

Gender violence occurs because of the unequal power dynamic between the genders and it is the manifestation of a political construct within the family. The perpetrator is usually the spouse, sibling or parent. Gender violence has recurring patterns and it becomes habitual with passage of time. The habituated offenders are triggered into violent behavior by the slightest provocation. Liquor and abuse of other substances aggravates the degree of force and lowers the threshold of provocation. Liquor and abuse of other substances aggravates the degree of force and lowers the threshold of provocation. Domestic violence in India is so pervasive that the Government has enacted special legislation for the protection of women. 


\section{INTERNATIONAL JOURNAL of RESEARCH -GRANTHAALAYAH

However, even the most evolved legislation cannot compensate for a lack of evolution in the social mindset. Violence against women has so many different faces that it is difficult to chronicle the various manifestations observed. It begins before the birth of a daughter and continues to haunt her till her death in subtle and gross ways. It could be foeticide, infanticide, neglect, malnutrition, denial of education, denial of livelihood, denial of resources, denial of opportunities, dowry violence, marginalization in the family or community and lack of proper nutrition and health care.

Without empowerment violence will not abate. Without education empowerment will not happen. Without political will education and empowerment are not viable. The political empowerment of women is fundamental for bringing about a radical change in their lives and living conditions (Social Welfare, 2008). Such empowerment can take place only through the adequate representation of women in political bodies and offices for decision making and policy making that affects women directly. A nation cannot prosper if half of its population is living lives of 'quite desperation', lives without options, where frustration is the norm and achievement is the exception. As part of the women's movement we have to bring a complete mutation of mines. With the revolution we will bring a new evolution.

\section{REVIEW OF LITERATURE}

Molina and Olga (2000) in his study integrate an ecological perspective \& trauma theory in proposing a model of effect of domestic violence on women's parenting and children's adjustment. One hundred and twenty women and their children between the ages of 7 and 12 participated. Results supported an ecological model of the impact of domestic violence on women and children. The model predicted $40 \%$ of the variance in children's adjustment, $8 \%$ of parenting style, $43 \%$ of material psychological functioning and $23 \%$ of martial satisfaction, using environmental factors such as social support, negative life events and material history of child abuse. Overall, results support the ecological framework and trauma theory in understanding the effects of domestic violence on women and children.

Domestic violence, birth outcomes, and child survival Several recent studies have also found that material experience of physical and sexual violence is significantly associated with an increased risk of under-five mortality, infant and fetal death, and low birth weight (Asling-Monemi et al, 2003; Jejeebhoy 1998; Campbell et al, 1999). Recent surveys have found that the prevalence of domestic violence (defined as physical beating or battering of a woman by a male intimate partner) ranges from 22 percent to 60 per cent in developing countries (Visaria 1999; Heise et al. 1994). The prevalence of psychological and emotional abuse (defined as a woman being threatened with physical abuse, ridiculed, or ignored) is believed to be even higher (Visaria et al, 1999; Heise et al, 1994). Analysis of DHS data from several countries clearly show that women and girls are more likely to experience violence when they are married at the youngest ages in adolescence (UNICEF 2005). The precursors of domestic violence are marital conflict, male 


\section{INTERNATIONAL JOURNAL of RESEARCH -GRANTHAALAYAH

control over household wealth and decision-making, poverty and unemployment (Heise 1998). Given the high prevalence of domestic violence and its impact on infant and child mortality, and birth outcome, it is important to explore the role of domestic violence on child nutrition, and it is reasonable to expect an association.

Tauchen, Witte and Long (1991) present a non-cooperative bargaining model in which violence serves both an expressive and an instrumental purpose' it enters the husband's utility directly as well as indirectly through his wife's behavior. In this model, men 'purchase;' violence from women with income transfers, so that the level of resources controlled by each partner and whether the reservation utility constraint is binding determine the level of violence in equilibrium. More recently, a paper by Robert Pollak (2002) attempts to explain the prevalence of domestic violence-as opposed to its causes-by modeling the inter-generational transmission of domestic violence.

\section{JUDICIAL EMPOWERMENT OF WOMEN}

The Judicial Empowerment of women includes the legal protection, provision of legal rights, and privileges to women must be made stronger, so as to protect the women's interest in the society. In this respect, legal-judicial system will be made more responsive and gender sensitive to women's needs, especially in cases of domestic violence and personal assault. New laws will be enacted and existing laws reviewed to ensure that justice is quick and the punishment meted out to the culprits is commensurate with the severity of the offence. At the initiative of and with the full participation of all stakeholders including community and religious leaders, the Policy would aim to encourage changes in personal laws such as those related to marriage, divorce, maintenance and guardianship so as to eliminate discrimination against women. The evolution of property rights in a patriarchal system has contributed to the subordinate status of women. The Policy would aim to encourage changes in laws relating to ownership of property and inheritance by evolving consensus in order to make them gender just.

The National Commission for Women (NEW) safeguards the interests of women with a mandate covering almost all aspects of women's rights. There are about 42 Central Acts concerning women, of which 32 Acts have been reviewed by the NCW for their efficiency and removing gender discriminatory provisions. In addition, the DWCD is also in the process of initiating new legislation amending existing ones so that they become more potent in protecting women. These include Protection of Women from Domestic Violence Act, 2005, which came into force on September 14, 2005. The Act seeks to provide immediate and emergent relief to women who face situations of violence in their homes. Protection against Sexual Harassment of Women Bill, seeking to confer on women the right to be protected from sexual harassment, is being drafted at the moment (Economic Survey 2005-06). There are certain legislations to prevent atrocities on women, enhancement of equal remuneration, preventing and punishment against sexual harassment of women at work place, domestic violence, and especially against social systems 


\section{INTERNATIONAL JOURNAL of RESEARCH -GRANTHAALAYAH

such as dowry, polygamy, etc, have already been passed and to execute the same, there are Women Courts and Women Police Stations established.

\section{DOMESTIC VIOLENCE IN KARNATAKA}

Empirical data has emerged in Karnataka, a state in south-western India of routine domestic violence against women resulting in death that has gone unpunished under the penal code of the country. Individual cases were reported to Vimochana a leading NGO engaged in providing support to battered women. In the light of what was disclosed in this process, volunteers decided to document the statistics maintained by police and related enforcement agencies. In the process they have stumbled upon basic flaws in the reporting and monitoring process which has helped in systematic concealment of horrifying data. Despite several efforts at raising this issue before the public and the administration, there is persistent unwillingness to accept the extent of the problem and finding methods to combat it.

Vimochana first attempted to bring specific cases of domestic violence that were being treated indifferently by the police before senior officials, ministers and legislators. Several meetings and conferences with police, medical, prosecuting and judicial personnel had limited results although it did produce a detailed working manual on how different agencies should handle cases of domestic violence. (Renuka Viswanathan; 2001) Despite several preparatory measures, the NGO was not permitted to set up a help line to provide immediate protection to victims of domestic violence or monitor police investigation. Training, sensitization and monitoring of personnel involved in investigation did not also take off.

After several protests and demonstrations, a truth commission was organized at Bangalore on August 15, 1999 in which two juries consisting of concerned and respected public figures heard individual cases of unpunished domestic violence and gave suggestions for procedural improvements. Persistent lobbying with political representatives results in the setting up of a joint house committee in the Karnataka assembly, which heard the departments concerned and produced a comprehensive report. These reports are still gathering dust.

Vimochana and other women's and human rights groups have repeatedly raised this issue before the National Human Rights Commission and the national and state women's commissions. The prevalence and size of the problem are yet to catch the attention of the public and of human rights enforcement agencies. One reason for this is of course the conspiracy of silence that operates in all societies to play down domestic violence and treat it as an acceptable adjunct to harmony within homes. Another reason is, however, the non-availability of statistics to disclose the enormity and prevalence of such violence.

\section{A VIEW OF AFZALPUR-}

Afzalpur is $2^{\text {nd }}$ biggest taluka in Karnataka State. It comes under Kalburgi District. Afzalpur is

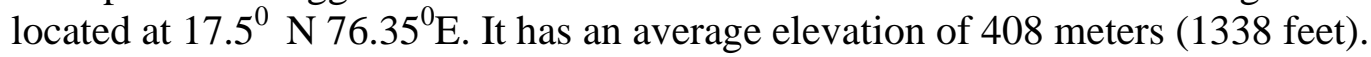




\section{INTERNATIONAL JOURNAL of RESEARCH -GRANTHAALAYAH

Afzalpur taluka borders Aland taluka to the North. Gulbarga Taluka to the east. Jewargi Taluka and Sindgi Taluka of Bijapur district to the south. Indi Taluka of to the west and Akkalkot taluka of Solapur district of Maharashtra to the north-east.

The total population in Afzalpur 2,20,339 as per the survey of census during 2011 by Indian Government of this about 1,93,251 people are living in the urban (town \& cities) area and about 1,93,251 are living in village ( rural area). There are 1,13,057 males and 1,07,282 females are there and total scheduled caste are 44,188, Total scheduled tribe are 2,146. More than 500 villages come under this taluka. The places undertaken in this study area, for surveying the reasons and implication of material violence on women

- Vithal Heroor Nagar

- Nimbal Tota

- Rajiv Gandhi Nagar

- Usmania colony.

Bases on these areas respondents are being selected and the present paper will discuss about the effects of domestic violence in the case study area of Afzalpur.

Table 1: Age and Educational Level of Respondents

\begin{tabular}{|l|l|l|l|l|l|l|l|l|}
\hline Educational Level & Age & \multicolumn{2}{|l|}{$20-30$} & $30-40$ & $40-50$ & Total \\
\hline Illiterate & 7 & $14 \%$ & 7 & $14 \%$ & 5 & $10 \%$ & 19 & $38 \%$ \\
\hline Primary & 6 & $12 \%$ & 7 & $14 \%$ & 5 & $10 \%$ & 18 & $36 \%$ \\
\hline Secondary & 5 & $10 \%$ & 4 & $8 \%$ & - & - & 9 & $18 \%$ \\
\hline Graduate & 3 & $6 \%$ & 1 & $2 \%$ & - & - & 4 & $8 \%$ \\
\hline Total & 21 & $42 \%$ & 19 & $38 \%$ & 10 & $20 \%$ & 50 & $100 \%$ \\
\hline
\end{tabular}

From the above table we can observe that violence is higher in the age group of 20-30(42\%), $1 \%$ of respondents were illiterate, $12 \%$ each had received minimum education, $10 \%$ o them had secondary education, only $6 \%$ of respondents are graduates. By observing the table we come to know that low level of education is reason for domestic violence, not only illiterates, graduates also suffer from domestic violence.

The educational back-ground partly supports the contention that educated women are more aware about their rights in the conjugal relationship and hence, this may raise questions with regard to asymmetrical martial relationship resulting into use of coercive methods by their husbands to maintain their superior positions. 


\section{INTERNATIONAL JOURNAL of RESEARCH -GRANTHAALAYAH \\ A knowledge Repository}

Social

Table 2: Class and Religion of Respondents

\begin{tabular}{|l|l|l|l|l|l|l|l|l|}
\hline Caste & Class & \multicolumn{2}{|l|}{ Higher } & \multicolumn{2}{l|}{ Middle } & \multicolumn{2}{l|}{ Lower } & Total \\
\hline Hindu & 4 & $8 \%$ & 12 & $24 \%$ & 6 & $12 \%$ & 22 & $44 \%$ \\
\hline Muslim & 4 & $8 \%$ & 10 & $20 \%$ & 8 & $16 \%$ & 22 & $44 \%$ \\
\hline Any other & - & - & 3 & $6 \%$ & 3 & $6 \%$ & 6 & $12 \%$ \\
\hline Total & 8 & $16 \%$ & 25 & $34 \%$ & 17 & $34 \%$ & 50 & $100 \%$ \\
\hline
\end{tabular}

From the above table we came to know that the middle class women are more suffering from domestic violence $50 \%$ of middle class women suffering from violence. $24 \%$ of them were Hindu Women. Women of all cultures and class are battered by husband men who are well respected in their communities give torture to their wives.

Table 3: The Factors for Husband Initiated Quarrel

\begin{tabular}{|l|l|l|}
\hline Factors & Frequency & Percentage \\
\hline Rude Behaviour & 20 & $40 \%$ \\
\hline Drinking behaviour & 10 & $20 \%$ \\
\hline Money matters and job related problems & 10 & $20 \%$ \\
\hline Extra Marital Relations & 10 & $20 \%$ \\
\hline Total & 50 & $100 \%$ \\
\hline
\end{tabular}

Table 3 reveals that drinking behavior is the reason for quarrel. The factor for husband initiated the quarrel $20 \%$ money matters and job related problems, $20 \%$ extra martial relations. To exert his dominant position in the conjugal relationship the husband uses rude behavior as a strategy to put his wife in a subordinate position. Another main factor attributed to the husband relates to money matters or his job related problems His failure to earn sufficient money and frustration at the job makes his very irritable and he gives vent to his frustration by picking up a quarrel with his wife. Another reason for quarrel is husband's drinking behavior pattern under the influence of the alcohol he may not only, indulge in vertical violence or may even use physical force.

Table 4: Domestic Violence Identified categories

\begin{tabular}{|l|l|l|}
\hline Identified categories of domestic violence & Frequency & Percentage \\
\hline Physical & 40 & $80 \%$ \\
\hline Sexual & - & - \\
\hline Emotional & - & - \\
\hline Above all & 10 & $20 \%$ \\
\hline Total & 50 & $100 \%$ \\
\hline
\end{tabular}

In the above table we come to know $80 \%$ women do not have any knowledge about 'Domestic violence'. They said only physical violence is called 'Domestic Violence'. Illiterate women 


\section{INTERNATIONAL JOURNAL of RESEARCH -GRANTHAALAYAH

thinks only beating, punching is the violence. Some graduates also do not have knowledge about violence only $20 \%$ of them identified the categories of 'Domestic Violence'.

Table 5: Women Still Live with Abusing Husband

\begin{tabular}{|l|l|l|}
\hline Reasons & Frequency & Percentage \\
\hline No other place to go & 10 & $20 \%$ \\
\hline For the sake of family reputation & 10 & $20 \%$ \\
\hline For the sake of children & 10 & $20 \%$ \\
\hline It is considered bad to live away from husband & 20 & $40 \%$ \\
\hline Total & 50 & $100 \%$ \\
\hline
\end{tabular}

In the above table we can see $40 \%$ women still living with abusing husband, because it is considered bad to live away from husband, $20 \%$ women had no other place to go, $20 \%$ for the sake of children and remaining $20 \%$ for the sake of family reputation. Our traditional society does not allowed women to leave her husband. Lack of Education and economic dependency are the main reasons to live with abusing husband.

\section{LAWS PERTAINING TO DOMESTIC VIOLENCE}

International conventions, the constitution and various other legal provisions provide for certain rights for women. The Universal Declaration of Human Rights and Convention or Elimination of all forms of Discrimination Against Women (CEDAW) do enforce certain special rights and privilege for women. Some of these have already been adopted by the farmers of our constitution. Equality of sexes is enshrined in the Constitution of India as a fundamental right and any law which discriminates on the grounds of religion, race, caste, sex or place of birth is held to be contrary to the Constitution as held in Article-15. The clause 3 of the aforesaid article specifically provides for the state to make special provisions for women and children. Article 39 directs state not to discriminate on the ground of sex and it should direct its policy towards securing equal pay for equal work irrespective of sex.

Several laws have been enacted to improve their social status, economic independence, political participation and professional growth. Various welfare schemes have been launched by the Government to raise the status of women. The law provides certain remedies to the victims of violence. We have provisions like section 498(a) and subject of section 30(A) of I.P.C. specially relating to subject of domestic violence. 


\section{INTERNATIONAL JOURNAL of RESEARCH -GRANTHAALAYAH

\section{PROTECTION OF WOMEN FROM DOMESTIC VIOLENCE - 2005}

In exercise of the powers conferred by Section - 37(1) of the "Protection of Women from Domestic Violence Act, 2005 ( of 2005)" passed by the Central Government made this Act for control and protection of women from Domestic Violence in the Country.

The observations made from the study Area are:

1 Women should take care of themselves.

2 Women should increase their educational levels.

3 Women should know about the laws and facilities which are made for them by the Government.

4 Women should develop their self-confidence.

5 Women should raise their voice against violence and not to tolerate any kind of Violence.

6 They should not believe any type of traditional; move.

7 Parents-in-laws should treat their daughter-in-laws as their daughter.

8 Husband should give respect to her wife, should not treat her like slave.

\section{VIOLENCE AGAINST WOMEN AREAS OF CONCERN}

It is a paradox of modern India that women yield power and hold positions at the top yet large sections of women are among the most underprivileged. The clearest indicator of discrimination against women is the skewed sex ration. There are 933 females in India per 1000 as against the world average of 990-1000. No doubt, globalization has made an impact on the cause of violence against women. Integrated measures to prevent and eliminate violence have been initiated. But for this, an exhaustive study of the causes and consequences of violence against women is to be done and the effectiveness of preventive measures is to be scaled. In absence of these prominent measures, the States fail to take the basic steps needed to protect women from all sorts of violence and thus allow all the crimes to be committed with impunity, resulting in to failure in their obligation to protect women from torture.

Ever since the globalization of this demonic problem, many legal measures have been adopted and implemented by the society. Acts such as passing of violence against women bills, empowering the non-government organizations; massive public education campaigning to destroy the dangerous myths perpetuating violence;' pressing for suffer laws etc. have been formulated. While we praise all the above accomplishments, work yet remains to be done in the area of prevention and eradication. Cutting-edge pilot programs must be developed to handle these issues. Programs must further educate the community at large about the ways they can prevent and rid the society violence against women. Both men and women can be empowered to tackle these issues, by confronting established values and norms for women's, reinforced by mainstream media, the entertainment industry and conservative religious groups, only to name some from our political leaders and insist on measures that will lead to prevention, accountability 


\section{INTERNATIONAL JOURNAL of RESEARCH -GRANTHAALAYAH

and the eventual eradication of all types of violence against women. We should realize that stopping violence is not only a women's issue. It must also be a school, workplace, community and national area of vital concern.

Finally, findings may propose the following actions should be taken determinatively by the Civil Society, the State and the People to stop violence against women.

1 To condemn violence against women and refrain from invoking any custom, tradition or religious consideration which is against the freedom of women.

2 To adopt/implement and periodically review/analyze laws to ensure efficacy of legal measures.

3 To create/strength institutional mechanism so that women can report acts of violence against them in a safe and confidential environment.

4 To ensure that women with disabilities have access to information and services in the field of violence against women.

5 To allocate adequate resources within the Government budget and mobilize community resources.

6 To adopt laws, wherever necessary, and reinforce the existing laws that punish security forces, police or any other agents of the state who engage in acts of violence against women in course of performance of their duties.

7 To promote a transparent policy of mainstreaming a gender perspective in all policies and programs related to violence against women.

8 To pressurize and enforce legislation against perpetrators of practices and acts of violence against women such as female infanticide, dowry-related violence, parental sex selection, female genital mutilation etc.

9 To support initiatives of women's organizations and NGO's all over the globe to raise awareness and to contribute to its elimination.

10 To recognize the vulnerability to violence and other forms of abuse

11 To promote research, collect data and compile statistics, especially concerning domestic violence relating to prevalence of different forms of violence against women.

12 To disseminate findings of research and studies widely.

13 To render relief support and well-funded shelters for women subjected to violence.

It is high time we realize that violence against women is a violation of human rights that cannot be justified by any religious, political or cultural claim. A global culture of discrimination against women allows violence to occur daily and with impunity. We should eradiate violence against women and help women to achieve lives of equality and human dignity (Social Welfare 2008)

\section{CONCLUSION}

The attempt has been made in this paper about domestic violence on women and a profile of domestic violence on women and their problems in the families of the case study area of Afzalpur. An important point is to be noted here, that illiterate women suffered more from 


\section{INTERNATIONAL JOURNAL of RESEARCH -GRANTHAALAYAH

violence between the age group of 20-30. Middle class women suffered more than the other classes. Women should take help from women's organizations. They should consult to counselor how to solve their problems. Violence against women exists in various forms in everyday life in all societies. Women victims of violence should be given special attention and comprehensive assistance. To this end, legal measures should be formulated to prevent violence and to assist women victims. Change is needed in the perception of society towards the dignity of women. Awareness against gender biases is necessary to minimize the problem. There is need to motivate the poor families to utilize the various schemes started by the Govt. for their welfare. Strict legal action should be taken against those who are involved in violence related activities against women.

Strengthening and increasing of non-Government organizations which could take up individual problems. Women in general must be educated about their rights, the agency to be approached. Family counseling centers must be set up at lower levels, so that families at risk can be identified and helped. Mahatma Gandhi says 'As long as women of India do not take part in public life there can be no salvation for the country". Violence against women does not end by merely bestowing of judicial rights or by making women literate. Most urban women are literate today but they are also victims of domestic violence. It is imperative that women must be morally strong and empowered.

\section{REFERENCES}

[1] Asling-Monemi, K.R., Pena, M.C. Ellsberg, and L.A. Persson (2003), "Violence Against Women Increases the Risk of Infant and Child Mortality; A Case-Reference Study in Nicaragua', Bulletin of the World Health organization, 81: 10-6.

[2] Compbell, J.S. Toress, J.Ryan, C. King, D.W. Campbell, R.Y. Stallings, and s.C. Fucha (1999), 'Physical and Nonphysical Partner Abuse and Other Risk Factors for Low Birth Weight Among Full Term and Preterm Babies', American Journal of Epidemology, 150: 714-26.

[3] Domestic Violence and Birth Control Sabtoage: A Report from the Teen Parent Project 2000. Center for Impact Research, Chicago, IL, Available at http://www.impactresearch.org/documents/dvndbirthcontrol.pdf.

[4] Economic Survey (2005-06), “Empowerment of Women”, http://indiabudget.nic.in accesed on $25^{\text {th }}$ December 2008.

[5] Farmer, A. and Thiefentharler, J. (1996), "Domestic Violence: The Value of Services as Signals, ”. The American Economic Review, 86.2: 274-279.

[6] Frye, V. (2001), 'Examining Homicide's Contribution to Pregnancy-Associated Deaths." The journal of the American Medical Association, 285 (11).

[7] Heise, L.L., a. Raikes, C. H. Watts, and A.B. Zwi (1994), 'Violence Against Women; A Neglected Public Health Issuein Less Developed countries'. Social Science Medicine 39: 1165-79. 


\section{INTERNATIONAL JOURNAL of RESEARCH -GRANTHAALAYAH \\ A knowledge Repository}

Social

[8] Heise, L.L. (1998), 'Violence Against women. An Integrated Ecological Framework' Violence Against Women, 4: 262-90.

[9] Jajeebhoy, S.J. (1998), Associations between Wife-beating and Fetal Infant Death; Impressions from a Survey in Rural India Studies in Family Planning, 29: 300-8.

[10] Levinson, D. (1989), Family Violence in Cross-Cultural Perspedctives, Newburry Park. CA: Sage Publications.

[11] McFarlane, J. et. Al (1996), "Physical Abuse, smoking and Substance Abuse during Pregenancy, prevalence, Interrelationships and Effects on Birth Weight." Journal of Obstetrical Gynecological and Neonatal Nursing, 25: 313-320.

[12] UNICEF (2005), "Early Marriage: A Harmful Traditional Practice. A Statistical Exploration'. United Nations Children Fund: New York.

[13] Robert A. :Pollak (2002), “An Integenerational Model of Domestic Violence”. NBER Working Paper, 9099.

[14] 'Social Welfare' (Dec. 2008)ISSN 0037-8038, Vol. 55, No.9, pp.5.

[15] Ibid., pp.6-7

[16] Ibid., pp.26-27

[17] Renuka Viswanathan (2001), Economic and Political Weekly, June 16,2001 PP. 2175

[18] Tauchen, H.V., Witte, A.D. and Long. S.K.(1991), 'Domestic Violence; A NonrAndom Affair, "International Economic Review, 32, 2: 491-511.

[19] Tauchen, H.V. (1995), 'The Dynamics of Domestic Violence's," The American Economic Review, 85, 2: 414-418

[20] 'Violence Against Women: Effects on Reproductive Health'. Outlook, Volume 20, No. 1, September 2002: Available at http://www.path.org/files/EO2 L20_1.pdf.

[21] Visaria, L., N., Mittra, V. Poonacha, and D. Pandey (1999), "Domestic Violence in India; A Summary Report of Three Studies', International Center for Research on Women (ICRW): Washington, DC. 